\title{
THE INFLUENCE OF A SIX MONTH AEROBICS PROGRAMME ON MIDDLE AGED WOMEN'S AEROBIC CAPACITY AND BODY COMPOSITION
}

\author{
Barbora Šeděnková, Pavel Stejskal ${ }^{1}$, Jaroslav Šimíček ${ }^{2}$, Milan Elfmark, \\ Tereza Bušinová ${ }^{3}$, Barbora Raníková ${ }^{3}$
}

\author{
Faculty of Physical Culture, Palacký University, Olomouc, Czech Republic \\ ${ }^{I}$ Faculty of Sports Studies, Masaryk University, Brno, Czech Republic \\ 2 Faculty of Medicine, University of Ostrava, Ostrava, Czech Republic \\ 3 Pedagogical Faculty, University of Ostrava, Ostrava, Czech Republic
}

Submitted in February, 2012

BACKGROUND: Regular physical activity has a positive influence on increasing physical fitness, which has considerable impact on health and, consequently, on the quality and length of human life.

OBJECTIVE: The aim of the study was to assess the influence of six months of physical endurance activity on the body composition and aerobic capacity of middle aged women.

METHODS: Forty women between the ages of 40 to 55 years with a sedentary occupation and without regular physical activity took part in the study. The experimental group $(\mathrm{n}=21)$ participated in dance aerobics lessons combined with strength training three times a week for 6 months, during exercise heart rate was monitored by heart rate monitors. The control group $(n=19)$ did not change their lifestyle during the observed period. All participants passed an all-out bicycle ergometer test to exhaustion and anthropometric measurement (bioelectrical impedance analysis method) before and after this six month program.

RESULTS: In the experimental group, after finishing the intervention programme, positive changes were perceptible in almost all monitored parameters; specifically an increase of fat free mass in the lower limbs, peak oxygen consumption, and the duration of the exercise test was statistically significant. Although, in the control group, some monitored parameters changed almost identically; the amount of fat free mass decreased and the duration of the exercise test diminished. Analysis of variance at repeated measurements confirmed that the intervention programme had a statistically significant and positive effect on the duration of the exercise test and on the amount of muscle and fat free mass in the right lower limb.

CONCLUSIONS: Physical intervention had a statistically important positive influence on the amount of muscle and fat free mass in the right lower limb and on the duration of the exercise test (also logically significant). The results were affected by the women's poor adherence to the aerobics programme, large differences in their motivation and the relatively low training intensity. Despite some inconsistent results, it can be said that an intervention programme in a style of aerobic dance combined with strengh training is suitable physical activity for increasing physical fitness in sedentary middle aged women.

Keywords: Bioelectrical impedance analysis, fat mass, cardiorespiratory fitness, aerobic dance, sedentary women.

\section{INTRODUCTION}

The fact, that regular physical activity of a proper intensity and volume is a very important part of a healthy lifestyle, is already commonly known. A number of authors demonstrate in their studies that an active lifestyle and good fitness has considerable influence on health and, consequently, on the quality and length of human life (Fletcher et al., 2001; Warburton, Nicol, \& Bredin, 2006). Physical inactivity, together with excessive food intake, belongs to the important risk factors contributing to obesity and cardiovascular and metabolic diseases development (Stejskal, 2000; Warburton et al., 2006).
Physical activity is important during one's whole life, however its importance and need increases with aging (Šimonek, 2000). With advancing age, the risk of metabolic and cardiovascular diseases rises. It is a consequence of age related physiological and other changes, which are accompanied by decline of aerobic capacity or changes in body composition (Hawkins \& Wiswell, 2003; Hughes, Frontera, Roubenoff, Evans, \& Fiatarone Singh, 2002). Since some studies demonstrate, that age associated decline in aerobic capacity and lean body mass have a slower decline in athletes and active individuals than in sedentary individuals (Hawkins \& Wiswell, 2003; Hughes et al., 2002), it is evident that lifestyle can influence these changes. 
In menopausal women, the risk of the above mentioned diseases may be accelerated by hormonal changes (Silva, Costa-Paiva, Pinto-Neto, Braga, \& Morais, 2005). In postmenopausal women, the lack of estrogen can cause an acceleration of age associated bone loss (Manolagas, 2010) and muscle mass loss. One of the possibilities for how to influence and slow down the number of menopausal associated symptoms is a change of lifestyle and enhancement of physical activity (Asikainen, Kukkonen-Harjula, \& Miilunpalo, 2004; Asikainen et al., 2002). However, according to Boháčková and Kolouch (2001), it is more efficient to change a life style before climacterial.

Physical activity, which has a positive influence on physical fitness improvement, is according to the American College of Sports Medicine (ACSM) any activity that uses large muscle groups, is rhythmical and naturally aerobic (walking, jogging, cycling) (Pollock et al., 1998). For an improvement in $\mathrm{VO}_{2} \max$ and body composition it should be practised 3-5 times a week (Asikainen et al., 2002; Pollock et al., 1998), with an intensity of $50-85 \%$ of $\mathrm{VO}_{2} \max$, with a total energy output of 700-2000 kcal per week (2.93-8.36 MJ) (Asikainen et al., 2002). Numerous studies demonstrated that combined aerobic and resistance training is suitable for menopausal women (Asikainen et al., 2004).

Aerobics, which matches the above mentioned recommendations, belong to the most popular women's group workouts in recent years. The ACSM also presents aerobics as a suitable physical activity for physical fitness improvement (Pollock et al., 1998). Many studies confirm the positive effect of aerobics on middle aged women's cardiorespiratory fitness and body composition (Bell \& Bassey, 1994; Çakmakçi, Arslan, Taşkin, \& Çakmakçi 2011; Robles Gil et al., 2012; Stejskal et al., 2007), but they apply only dance or step aerobics in their researches. However, the type of lessons which combine aerobic dance with resistance training or which are focused on strengthening remain missed. Due to strengthening, the intensity level of these lessons might be lower; therefore, the influence on fitness might be different.

The aim of the study was to assess the influence of six months of dance aerobics combined with strenght training on the body composition and aerobic capacity of women between the ages of 40 to 55 years with a sedentary occupation and without regular physical activity.

\section{METHODS}

\section{Subjects}

The research sample consisted of 40 healthy women between the ages of 40 to 55 years $(M=46.68$; $S D=$ 3.39), with a sedentary occupation and without regular physical activity.
Entrance criteria were an interest in exercise, a health state allowing participation in the exercise programme, the appropriate age, sedentary occupation and signing informed consent. Fulfillment of these conditions was tested by a short interview.

Thirty women, who met the above mentioned conditions, expressed their interest in regular training and participation in the project. The medical entrance exam excluded another two of them. It was not possible to divide such a small sample into an experimental and acontrol group, therefore, the control group (another 20 women) was made of women who also matched above mentioned entrance criteria, but in contrast to the participants from the experimental group, they were not interested in changing their actual lifestyle and regular physical activity. Accordingly, women were not divided randomly but based on their interest in physical activity.

The experimental group, made up of 28 women, were to complete dance aerobics lessons combined with strength training under the supervision of experienced and professional coaches regularly three times a week for 6 months. Before starting and after finishing this programme the participants completed initial and final laboratory testing. Due to seven women not taking part in the final checkup, the experiment will only use the data from 21 women.

The control group, primarily made up of 20 women, did not change their lifestyle during the observed period. In the same period, the women from the control group took part in a similar initial and final laboratory testing to that of the women from the experimental group. Only 19 women from the control group completed the program.

The main aim of this project was not to change participants' aerobic capacity or body composition at any cost, but to find out, how the used active intervention can affect these indicators. Any changes in nutrition or habitual physical activity could distort the results. For the same reason women did not use any nutritional supplements.

\section{Laboratory tests}

Before starting and after finishing the intervention programme, all participants completed initial and final laboratory testing, within that they passed anthropometric measurement by tetrapolar bioelectrical impedance analysis (BIA) method and an all out bicycle ergometer test to exhaustion on the bicycle ergometer. Before the measurement itself was carried out, women passed the entrance medical check up, where the women's anamnesis were taken, a static electrocardiogram (12 - lead ECG, BTL - $08 \mathrm{MT}+$, Czech Republic) recorded, and blood pressure (BP) by mercury manometer (Chirana T 40, Slovakia) measured to exclude possible heart or vascular diseases which would contra-indicate the exercise. In the case where hypertension at rest was detected 
( $\geq 140 / 90$ - Chobanian et al., 2003), blood pressure was also measured during the exercise test.

Participants completed an all out bicycle ergometer test to exhaustion on a bicycle ergometer (Lode Corival, Netherlands). It was a continuous multistage test with a quick rise of the load to a maximum according to Jirák et al. (2004). A short initial phase (30 seconds without any load and 30 seconds with a load of 10 watts [W]) served as training. Then the load was increased to $25 \mathrm{~W}$ and kept increasing every minute by $25 \mathrm{~W}$ until reaching a subjective maximum. All stages of a load lasted one minute. The maximal testing was finished due to exhaustion and the inability to keep a pedal frequency of $60 \mathrm{rev} . \times \mathrm{min}^{-1}$ (Jirák et al., 2004). Analysis of breath gases was carried out using a gas analyser (Zan 600 USB, nSpire Health, Germany).

The data obtained during the maximal cycling test was also used for setting the optimal exercise intensity for each woman in the experimental group in the aerobics lessons. The exercise intensity of each woman was monitored and controlled using heart rate monitors (Polar S610i, Polar Electro, Finland) during the aerobics lessons.

Body composition was assessed by the BIA method, using a single frequency tetrapolar Tanita BC - 418 MA Segmental Body Composition Analyzer (Tanita Corporation, Japan). BIA method is based on the principle of different electrical characters of lean tissue, body fat and body water. For the total body water (TBW, basic variable) estimation, BIA uses low level electrical current $(800 \mu \mathrm{A})$ with a fixed frequency $(50 \mathrm{kHz})$, which measures particular biological tissues conductivity. Fat free mass (FFM) which contains large amounts of water and electrolytes, is a good electrical conductor, by contrast fat mass (FM) which is anhydrous, acts like an insulator (Riegerová, Přidalová, \& Ulbrichová, 2006; Wagner \& Heyward, 1999). BIA method is considered as a sufficiently valid and reliable method for the assessment of body composition in healthy subjects with a body mass index (BMI) $16-34 \mathrm{~kg} \times \mathrm{m}^{-2}$ without abnormal hydration, if the standard measurement conditions are observed (Kyle et al., 2004).

The BIA measurements run adhering to the manufacturer's guidelines (Tanita BC 418 MA Instruction Manual, 2002). Height, sex and age were entered manually, while weight was recorded automatically. The Tanita software uses inbuilt prediction equations for the body composition calculation with regard to subjects' activity level (category "standard" for a common individual or category "athlete" for an active individual). The women were classified standard. Standard measurement conditions were observed (Heyward \& Wagner, 2004; Kyle et al., 2004).

Using this method the following parameters were attained - body weight ( $\mathrm{kg})$, total amount of FM, FFM,
TBW and muscle mass (MM); the parameters, except for body weight, are shown both in absolute values $(\mathrm{kg})$ and in relative values ( $\%$ of body weight). The values of FM, FFM and MM were monitored according to particular body segments such as - upper and lower limbs and trunk. Additional to the above mentioned parameters, BMI was also calculated.

Participants also passed the spectral analysis of heart rate variability according to the method described by Salinger et al. (1998), but the results of this measurement are not the object of this study. The exception is only the resting heart rate values $\left(\mathrm{HR}_{\text {rest }}\right)$, which were obtained during clinostasis and were necessary for a setting of optimal exercise intensity for each woman.

\section{Active intervention}

The active intervention lasted for 6 months. Exercise lessons were regularly organised on Monday, Wednesday, and Friday. The lessons were supervised by three professional instructors especially trained for the given type of aerobics lesson.

\section{Lesson structure}

The initial part of the lesson (Warm up and dynamic stretching) (approximately 15 minutes) serves for warming up the body and preparing it for a sequential load. During this part, the women were taught dance choreography in its basic and low impact form and this choreography was consequently used during the main part of the lesson. The choreography was usually created using two or three symmetric blocks.

Low impact steps are based on walking, at least one foot remains on the floor. On the other hand, high impact steps come from skips and runs and when both feet are off the ground at the same time.

In the main part of the lesson (approximately 35 minutes), the choreography was developed and bodybuilding elements were inserted into the dance choreography. Holding pattern and Layering methods, which replace basic steps with other more complicated steps or isotonic bodybuilding elements, were used (Šeděnková, 2007).

Cool down followed by repeating the basic aerobics steps in low impact form (approximately 3 minutes) and static isometric and isotonic boosting of chosen upper body muscle groups (e.g. strengthening back muscles, arms) (approximately 5 minutes).

At the end of each lesson, the strengthening of abdominal muscles passed and followed both final static stretching of all muscles that worked during the training session and the postural muscles.

During every lesson, a new choreography composed of low impact as well as high impact steps was taught. Considering that women participated in this study were middle aged, sedentary and less fit, dance choreogra- 
phies were primarily composed of low impact elements. Boosting elements were focused on the lower body muscles and were integrated directly into the choreography.

In the initial and main part of the lesson recommended music tempo was $135-140$ beats $\times$ min $^{-1}$ (BPM), in the cool down part and during the strengthening it was 130 BPM. At the starting phase of the intervention program (the first two weeks of the intervention program - Stejskal \& Hejnová, 1992), instructors used a slower pace music and easier choreographies.

In the period of the third month up to the sixth month of the active intervention the women's heart rate was monitored by heart rate monitors (Polar) in every aerobics lesson. The recommended (optimal) heart rate $\left(\mathrm{HR}_{\mathrm{opt}}\right)$ of each woman was calculated according to the below mentioned formula (Stejskal \& Hejnová, 1993). The lower limit of recommended workout zone (10 BPM) was derived from the $\mathrm{HR}_{\mathrm{opt}}$ lowered by 10 BPM.

$$
H R_{\text {opt }}=\left[\left(0.003 \times V O_{2} \max \times k^{-1}\right)+0.6\right] \times[1.05 \times
$$
$\left.\left(H R_{\text {max }}-H R_{\text {rest }}\right)\right]+H R_{\text {rest }}$ where $H R_{\text {opt }}$ - optimal heart rate (recommended exercise intensity) [beats $\times \min ^{-1}$ ], $\mathrm{VO}_{2} \max \times k^{-1}$ - maximal oxygen consumption [ $\mathrm{ml} \times$ min. ${ }^{-1} \times \mathrm{kg}^{-1}$ ], $H R_{\text {max }}$ - maximal heart rate [beats $\times$ min. ${ }^{-1}$ ], $H R_{\text {rest }}$ - resting heart rate [beats $\times \min ^{-1}$ ].

Since only 15 monitors were available, women rotated them among themselves after each week. Data of heart rate monitoring were regularly copied into a computer, consequently from the whole training unit the maximal heart rate $\left(\mathrm{HR}_{\max }\right)$ and duration within the recommended zone $\left(\mathrm{t}_{\mathrm{rz}}\right)$ of each woman was found. The average heart rate $\left(\mathrm{HR}_{\mathrm{x}}\right)$ and circulation loading (Stejskal \& Hejnová, 1993) by the relative utilization (\%) of the maximal heart rate reserve $\left(\mathrm{HRR}=\mathrm{HR}_{\max }-\mathrm{HR}_{\text {rest }}\right)$ were also calculated in the initial and main part of the lesson.

One of the aims of the study was to find out what is the natural reaction of a female human to a given type of lesson, therefore women were not motivated to monitor and adhere to their training intensity regularly.

\section{Statistical analysis}

In the study a regular intervention program was the independent variable (regular aerobics lessons with given intensity and size) and chosen indicators of fitness (body composition, $\mathrm{VO}_{2} \max$ and next parameters characterizing cardiorespiratory fitness) were the dependent variables.

Data were analysed using the Statistica 8programme. Firstly, the basic statistical magnitudes were calculated for all monitored parameters (mean, standard deviation, minimum value, maximum value). A change of each watched parameter is expressed as a difference of the average value after intervention and the average value before intervention. For the statistical assessment of changes in particular indicators before and after the intervention, the analysis of variance at repeated measurements (ANOVA) and a post-hoc test (Fischer's LSD test) were used. Fischer's LSD test was also used for the statistical evaluation of the differences in the initial and final values between the experimental group and the control group. Logical significance (effect size) for the ANOVA was expressed by the coefficient $\eta^{2}$, whereas the values $\eta^{2} \geq 0.14$ predicate of high logical significance (Morse, 1999). The level of statistical significance was set to $\mathrm{p} \leq 0.05$ for all statistical analysis.

\section{RESULTS}

Ideally, women could participate in 69 aerobics lessons (TABLE 1). The mean attendance for one lesson was 14 women and each woman visited an average of 46 lessons (approximately 67\%). TABLE 1 shows selected descriptive statistics of parameters that distinguish exercise intervention, which were obtained from heart rate monitors. The average training intensity in the initial and main part of the lesson was 54.8\% HRR. From the whole training unit, the duration within the recommended zone was on average nearly 10 minutes.

TABLES 2, 3 and 4 show the basic characteristics of the research sample and the differences between the average entering and average outgoing data of both groups. Women with an average BMI were at the low limit of being overweight (National Heart, Lung, \& Blood Institute, 1998) for the initial diagnostics, an amount of body fat corresponding to standard rates for the given age and gender group (Heyward \& Wagner, 2004; Tanita BC 418 MA Instruction Manual, 2002). The amount of total body water was slightly below normal values (Riegerová et al., 2006). The initial rate of aerobic capacity was moderately under the standard limit in the experimental group; in the control group, it achieved the standard limit (Fletcher et al., 2001). The rates of maximal performance concurred with the average rates for a healthy population (Placheta et al., 2001).

The post-hoc test demonstrated that even if both groups were not homogenous, the differences between them were not statistically relevant (TABLE 5). In the experimental group, there was an improvement in almost all parameters, but changes were not statistically significant, as shown in TABLE 5. Significant enhancement in aerobic capacity was attained not only in the experimental group, but in $\mathrm{VO}_{2}$ peak $\times \mathrm{kg}^{-1}$ also in the control group (TABLE 5). In contrast to the control group, women from the experimental group achieved a higher performance in the exercise test after the intervention programme and the duration of the exercise test was significantly longer. 
Due to the futility of detecting the quantity of body fat in segments of limbs and because of the statistically insignificant changes in the parameters, the results are not shown in the tables. The only exception is the increase of muscle and fat free mass in the lower limbs in women from the experimental group, which was statistically significant to the changes in the parameters in the control group.

The analysis of variance at repeated measurements confirmed that regular physical intervention had, under these experimental conditions, a statistically significant positive effect on the duration of the exercise test (also logically significant) and on the amount of muscle and fat free mass in the right lower limb (TABLE 5).

\section{TABLE 1}

Selected descriptive statistics of exercise intervention

\begin{tabular}{|c|c|c|c|c|}
\hline & $M$ & $S D$ & Min. & Max. \\
\hline$n_{t u}$ & 46.41 & 17.34 & 9.00 & 68.00 \\
\hline$n_{t u} \%$ & 67.26 & 25.14 & 13.04 & 98.55 \\
\hline$N$ & 13.80 & 3.09 & 4.00 & 20.00 \\
\hline$H R_{m}$ & 145.70 & 14.61 & 106.00 & 176.00 \\
\hline$H \boldsymbol{R}_{x 45}$ & 120.79 & 13.49 & 81.32 & 155.67 \\
\hline$H R_{x 60}$ & 115,92 & 12,78 & 79,35 & 148,15 \\
\hline$\% H R R$ & 54.81 & 12.70 & 15.4 & 94.77 \\
\hline$t_{r z}$ & $9: 27$ & $5: 48$ & $0: 00$ & $26: 10$ \\
\hline$t_{40 \% H R R^{+}}$ & $37: 54$ & $10: 31$ & $0: 00$ & $58: 20$ \\
\hline$t_{50 \% H R R^{+}}$ & $29: 25$ & $12: 05$ & $0: 00$ & $53: 10$ \\
\hline$t_{60 \% H R R^{+}}$ & 19:11 & $12: 55$ & $0: 00$ & 49:10 \\
\hline
\end{tabular}

Legend: $n_{t u}$ - number of training units passed by 1 woman, $n_{t u} \%$ - number of training units passed by 1 woman in relative values (\%), $N$ - number of women present on one training unit, $H R_{m}$ - maximum heart rate in the aerobics lesson [beats $\times \mathrm{min}^{-1}$ ], $H R_{x 45}^{m}$ - average heart rate in the initial and main part of the aerobics lesson [beats $\left.\times \min ^{-1}\right] H R_{x 60}$ - average heart rate of the whole aerobics lesson [beats $\times \mathrm{min}^{-1}$ ], \% HRR - exercise intensity in \% of maximal heart rate reserve in the initial and main part of the aerobics lesson, $t_{r z}$ - average duration of exercise in the recommended zone [min.], $t_{40 \% H R R+}$ - average duration of exercise at the intensity above $40 \% \mathrm{HRR}$ [min.], $t_{50 \% \mathrm{HR} R^{+}}$- average duration of exercise at the intensity above $50 \% \mathrm{HRR}$ [min.], $t_{60 \% H R R^{+}}$- average duration of exercise at the intensity above $60 \% \mathrm{HRR}$ [min.], $M$ - arithmetic mean, $S D$ - standard deviation, Min. - minimum value, Max. - maximum value

\section{DISCUSSION}

Even though at the beginning of the project the women's motivation and their interest in participation in the project were great, their attendance of lessons graduallyfell. While in the first month of the active intervention, there were on average 17 women in the training unit, in the last month of intervention, only 11 women on average participated in the lesson. Eight participants showed $80 \%$ adherence during the intervention period, what can be considered as a high adherence (Willis \& Campbell, 1992), on the other hand 5 women visited less than $40 \%$ training units, what is according to Willis and Campbell (1992) a mark of low adherence.

In addition Kováčová, Stejskal, Neuls, and Elfmark (2011) reached similar results. In their study, the average value of adherence in the first month of the intervention program was $85 \%$, during the last two months the average value of women's attendance was also slightly under $60 \%$. Results of both studies are in agreement with the Willis and Campbell (1992) theory that almost 50\% of individuals, who start their participation in some physical activity program, terminate during the first 6 months of that program. According to Kováčová et al. (2011), reasons for the different or possibly decreasing adherence to long lasting intervention exercise are mainly in psychological factors (motivation and personal characteristics) and objective reasons (health, family, work, etc.).

A level of attendance, together with its large interindividual variability, certainly had an influence on most results of the active intervention. There was a statistically significant decline in the BIA results for the control group. One of the causes of this surprising result is not only the loss of body fat mass, but also a decline in the absolute value of fat free mass (as well as muscle mass). In the experimental group, the decrease in BMI was not significant; no reduction of fat free mass and muscle mass was achieved, in contrast to the control group. On the contrary, there was an increase in these values. Statistically significant changes of the lower limbs composition in the group of exercising women can be linked to the intervention programme character.

Wilmore et al. (1999) mention that specific endurance active intervention, which lasts longer than six months, causes on average a loss of $1.6 \mathrm{~kg}$ of total body mass, $2.6 \mathrm{~kg}$ of fat mass (approximately $2.9 \%$ body fat) and an increase of $1 \mathrm{~kg}$ of fat free mass. Our experimental group lost on average only $1 \mathrm{~kg}$ of fat mass after the active intervention, and the mean increase of fat-free mass was only $0.09 \mathrm{~kg}(8 \%)$. The lower effectiveness of our intervention programme was probably caused by the relatively low and very varied adherence, often inadequate (low) training intensity, and the shorter duration of intervention.

Significant enhancement in aerobic capacity was attained not only in the experimental group, but in $\mathrm{VO}_{2}$ peak $\times \mathrm{kg}^{-1}$ also in the control group. Women from the experimental group, in contrast to the control group, improved their maximum performance and the duration of the exercise test lasted significantly longer. These results can indicate the better exercise economy, which can result from more effective muscle recruitment into motor patterns (related to motor learning), a more effective ATP generation or better muscle elasticity (Jones \& Carter, 2000). 
TABLE 2

Total body composition before and after the intervention programme

\begin{tabular}{|c|c|c|c|c|c|c|c|c|c|c|}
\hline \multirow{2}{*}{\multicolumn{2}{|c|}{ Indicator }} & \multicolumn{4}{|c|}{ Before } & \multicolumn{4}{|c|}{ After } & \multirow{3}{*}{$\begin{array}{c}\text { Change } \\
M \\
-0.81\end{array}$} \\
\hline & & \multirow{2}{*}{$\begin{array}{c}M \\
72.12\end{array}$} & \multirow{2}{*}{$\begin{array}{c}\boldsymbol{S D} \\
11.55 \\
\end{array}$} & \multirow{2}{*}{$\begin{array}{l}\text { Min. } \\
55.10\end{array}$} & \multirow{2}{*}{$\begin{array}{c}\text { Max. } \\
97.40\end{array}$} & \multirow{2}{*}{$\begin{array}{c}M \\
71.31\end{array}$} & \multirow{2}{*}{$\begin{array}{c}S D \\
10.71\end{array}$} & \multirow{2}{*}{$\begin{array}{l}\text { Min. } \\
53.00\end{array}$} & \multirow{2}{*}{$\begin{array}{c}\text { Max. } \\
89.50\end{array}$} & \\
\hline Woi ht & $E x$. & & & & & & & & & \\
\hline wetgit & Co. & 69.94 & 9.75 & 53.50 & 89.90 & 68.47 & 8.33 & 53.60 & 83.30 & -1.47 \\
\hline \multirow{2}{*}{$B M I$} & $E x$. & 26.74 & 4.58 & 20.30 & 36.20 & 26.34 & 4.20 & 19.00 & 33.30 & -0.40 \\
\hline & Co. & 25.50 & 2.64 & 21.70 & 31.10 & 24.82 & 2.50 & 20.90 & 30.60 & -0.68 \\
\hline \multirow{2}{*}{$T M M$} & $E x$. & 46.77 & 3.40 & 41.10 & 55.10 & 46.91 & 3.63 & 38.80 & 53.40 & 0.14 \\
\hline & Co. & 46.70 & 5.31 & 38.90 & 54.40 & 46.44 & 4.64 & 39.40 & 54.10 & -0.26 \\
\hline \multirow{2}{*}{$\% T M M$} & Ex. & 65.81 & 8.56 & 56.60 & 84.10 & 66.74 & 7.91 & 57.00 & 82.80 & 0.93 \\
\hline & Co. & 67.15 & 5.18 & 59.30 & 77.70 & 67.47 & 4.08 & 62.40 & 75.00 & 0.32 \\
\hline \multirow{2}{*}{$T F M$} & $E x$. & 22.96 & 9.36 & 5.60 & 39.40 & 21.91 & 8.41 & 7.30 & 35.80 & -1.05 \\
\hline & Co. & 20.76 & 5.93 & 10.80 & 32.70 & 20.04 & 4.80 & 11.30 & 27.80 & -0.72 \\
\hline \multirow{2}{*}{$\% T F M$} & Ex. & 30.60 & 9.16 & 9.80 & 40.40 & 29.72 & 8.30 & 13.00 & 39.90 & -0.88 \\
\hline & Co. & 29.27 & 5.49 & 18.10 & 37.70 & 28.95 & 4.30 & 21.10 & 34.30 & -0.32 \\
\hline \multirow{2}{*}{ TFFM } & $E x$. & 49.31 & 3.61 & 43.30 & 58.00 & 49.40 & 3.86 & 40.80 & 56.20 & 0.09 \\
\hline & Co. & 49.18 & 5.59 & 40.90 & 57.20 & 48.44 & 4.50 & 41.50 & 56.20 & -0.74 \\
\hline \multirow{2}{*}{$\%$ TFFM } & Ex. & 69.41 & 9.17 & 59.50 & 90.30 & 70.29 & 8.31 & 60.10 & 87.10 & 0.88 \\
\hline & Co. & 70.56 & 5.67 & 62.30 & 81.90 & 71.06 & 4.29 & 65.70 & 78.90 & 0.50 \\
\hline \multirow{2}{*}{ Impedance } & Ex. & $\begin{array}{l}573.48 \\
\end{array}$ & 57.30 & 473.00 & 705.00 & 568.48 & 55.73 & 452.00 & 674.00 & -5.00 \\
\hline & Co. & 582.53 & 63.65 & 476.00 & 709.00 & 589.79 & 53.49 & 486.00 & 663.00 & 7.26 \\
\hline \multirow{2}{*}{$T B W$} & Ex. & 36.11 & 2.65 & 31.70 & 42.50 & 36.16 & 2.82 & 29.90 & 41.10 & 0.05 \\
\hline & Co. & 35.99 & 4.10 & 29.90 & 41.90 & 35.38 & 3.35 & 30.40 & 41.10 & -0.61 \\
\hline \multirow{2}{*}{$\% T B W$} & Ex. & 50.83 & 6.73 & 43.60 & 66.10 & 51.44 & 6.08 & 44.00 & 63.70 & 0.61 \\
\hline & Co. & 51.60 & 4.20 & 45.60 & 60.00 & 51.96 & 3.04 & 48.10 & 57.80 & 0.36 \\
\hline
\end{tabular}

Legend: Weight - women's weight $[\mathrm{kg}], B M I$ - body mass index $\left[\mathrm{kg} \times \mathrm{m}^{-2}\right], \% T M M, \% T F M, \% T F F M$ - total muscle mass, fat mass and fat free mass [\%], TMM, TFM, TFFM - total muscle mass, fat mass and fat free mass [kg], Impedance - total body impedance [ $\Omega$ ], TBW total body water $[\mathrm{kg}], \% T B W$ - total body water [\%], Ex. - experimental group, Co. - control group, Before - values before the active intervention of the experimental group, After - values after the active intervention of the experimental group, $M$ - arithmetic mean, $S D$ - standard deviation, Min. - minimum value, Max. - maximum value, Change - difference between the mean value after and before exercise intervention

TABLE 3

Results of exercise examination before and after the intervention programme

\begin{tabular}{|c|c|c|c|c|c|c|c|c|c|c|}
\hline \multirow{2}{*}{\multicolumn{2}{|c|}{ Indicator }} & \multicolumn{4}{|c|}{ Before } & \multicolumn{4}{|c|}{ After } & \multirow{2}{*}{$\begin{array}{c}\text { Change } \\
M \\
\end{array}$} \\
\hline & & $M$ & $S D$ & Min. & Max. & $M$ & $S D$ & Min. & Max. & \\
\hline \multirow{2}{*}{$\mathrm{VO}_{2}$ peak } & $E x$. & 1.97 & 0.33 & 1.31 & 2.67 & 2.12 & 0.37 & 1.57 & 3.01 & 0.15 \\
\hline & Co. & 2.05 & 0.44 & 1.31 & 2.86 & 2.17 & 0.44 & 1.57 & 2.87 & 0.12 \\
\hline \multirow{2}{*}{$V O_{2}$ peak $\times \mathrm{kg}^{-1}$} & $E x$. & 27.72 & 5.84 & 16.04 & 40.62 & 30.16 & 5.64 & 18.72 & 43.67 & 2.44 \\
\hline & Co. & 29.39 & 4.25 & 22.95 & 35.54 & 31.53 & 4.18 & 25.08 & 39.04 & 2.14 \\
\hline \multirow{2}{*}{$W_{\max }$} & $E x$. & 163.10 & 26.95 & 100.00 & 200.00 & 169.05 & 26.11 & 125.00 & 225.00 & 5.95 \\
\hline & Co. & 163.16 & 29.31 & 125.00 & 225.00 & 160.53 & 30.41 & 125.00 & 225.00 & -2.63 \\
\hline \multirow{2}{*}{$W_{\max } \times \mathrm{kg}^{-1}$} & $E x$. & 2.30 & 0.47 & 1.56 & 3.51 & 2.40 & 0.43 & 1.71 & 3.39 & 0.10 \\
\hline & Co. & 2.34 & 0.30 & 1.67 & 3.04 & 2.34 & 0.34 & 1.84 & 2.86 & 0.00 \\
\hline \multirow{2}{*}{$H \boldsymbol{R}_{\max }$} & $E x$. & 165.81 & 13.16 & 136.00 & 188.00 & 166.29 & 10.61 & 141.00 & 191.00 & 0.48 \\
\hline & Co. & 166.58 & 12.75 & 135.00 & 188.00 & 162.32 & 12.37 & 135.00 & 183.00 & -4.26 \\
\hline \multirow{2}{*}{ Test duration } & $E x$. & 6.24 & 1.05 & 3.53 & 8.13 & 6.50 & 1.01 & 4.23 & 8.13 & 0.26 \\
\hline & Co. & 6.35 & 1.14 & 4.70 & 8.37 & 6.20 & 1.24 & 4.40 & 8.58 & -0.15 \\
\hline
\end{tabular}

Legend: $V O_{2}$ peak - peak oxygen consumption $\left[\mathrm{L} \times \min .{ }^{-1}\right], V O_{2}$ peak $\times \mathrm{kg}^{-1}$ - peak oxygen consumption $\left[\mathrm{ml} \times \min .{ }^{-1} \times \mathrm{kg}^{-1}\right], W_{\max }-\operatorname{maxi}-$ mum performance $[\mathrm{W}], W_{\max } \times \mathrm{kg}^{-1}$ - maximum performance [ $\left.\mathrm{W} \times \mathrm{kg}^{-1}\right], H R_{\max }$ - maximum heart rate [beats $\times$ min. ${ }^{-1}$ ], Test duration - duration of the exercise test [min.], Ex. - experimental group, Co. - control group, Before - values before the active intervention of the experimental group, After - values after the active intervention of the experimental group, $M$ - arithmetic mean, $S D$ - standard deviation, Min. - minimum value, Max. - maximum value, Change - difference between the mean value after and before exercise intervention 
TABLE 4

Composition of lower limbs before and after the intervention programme

\begin{tabular}{|c|c|c|c|c|c|c|c|c|c|c|}
\hline \multirow{2}{*}{\multicolumn{2}{|c|}{ Indicator }} & \multicolumn{4}{|c|}{ Before } & \multicolumn{4}{|c|}{ After } & \multirow{3}{*}{$\begin{array}{c}\text { Change } \\
M \\
0.14\end{array}$} \\
\hline & & \multirow{2}{*}{$\begin{array}{c}M \\
7.62\end{array}$} & \multirow{2}{*}{$\frac{S D}{0.64}$} & \multirow{2}{*}{$\begin{array}{r}\text { Min. } \\
6.60\end{array}$} & \multirow{2}{*}{$\begin{array}{r}\text { Max. } \\
9.10\end{array}$} & \multirow{2}{*}{$\begin{array}{c}M \\
7.76\end{array}$} & \multirow{2}{*}{$\frac{S D}{0.76}$} & \multirow{2}{*}{$\begin{array}{r}\text { Min. } \\
6.60\end{array}$} & \multirow{2}{*}{$\begin{array}{r}\text { Max. } \\
9.10\end{array}$} & \\
\hline & $E x$. & & & & & & & & & \\
\hline$R L M M$ & Co. & 7.68 & 0.91 & 6.10 & 9.00 & 7.58 & 0.77 & 6.20 & 9.10 & -0.10 \\
\hline \multirow{2}{*}{$R L \% M M$} & $E x$. & 59.39 & 6.90 & 49.60 & 73.30 & 60.67 & 6.66 & 50.40 & 74.20 & 1.28 \\
\hline & Co. & 61.06 & 4.40 & 54.40 & 68.80 & 61.61 & 3.44 & 56.20 & 68.90 & 0.55 \\
\hline \multirow{2}{*}{$R L F M$} & $E x$. & 4.94 & 1.59 & 2.30 & 8.30 & 4.71 & 1.44 & 2.10 & 7.20 & -0.23 \\
\hline & Co. & 4.49 & 1.04 & 2.80 & 6.80 & 4.32 & 0.85 & 2.90 & 6.20 & -0.17 \\
\hline \multirow{2}{*}{$R L \% F M$} & $E x$. & 37.07 & 7.26 & 21.30 & 47.30 & 35.59 & 7.09 & 21.40 & 46.60 & -1.48 \\
\hline & Co. & 35.24 & 4.67 & 27.10 & 42.40 & 34.75 & 3.64 & 27.50 & 40.40 & -0.49 \\
\hline \multirow{2}{*}{$R L F F M$} & $E x$. & 8.08 & 0.69 & 7.00 & 9.70 & 8.24 & 0.82 & 7.00 & 9.60 & 0.16 \\
\hline & Co. & 8.14 & 0.95 & 6.50 & 9.50 & 8.03 & 0.82 & 6.60 & 9.70 & -0.11 \\
\hline \multirow{2}{*}{$R L \% F F M$} & $E x$. & 62.91 & 7.22 & 52.70 & 78.30 & 64.41 & 7.09 & 53.40 & 78.60 & 1.50 \\
\hline & Co. & 66.34 & 8.77 & 57.60 & 97.10 & 65.25 & 3.64 & 59.60 & 72.50 & -1.09 \\
\hline \multirow{2}{*}{$L L M M$} & $E x$. & 7.54 & 0.59 & 6.80 & 9.10 & 7.66 & 0.71 & 6.60 & 8.90 & 0.12 \\
\hline & Co. & 7.48 & 0.85 & 6.00 & 8.60 & 7.39 & 0.70 & 6.10 & 8.70 & -0.09 \\
\hline \multirow{2}{*}{$L L \% M M$} & $E x$. & 59.47 & 6.63 & 51.10 & 74.30 & 60.87 & 6.26 & 52.80 & 72.60 & 1.40 \\
\hline & Co. & 60.65 & 4.16 & 54.80 & 68.20 & 61.16 & 3.35 & 55.70 & 68.60 & 0.51 \\
\hline \multirow{2}{*}{$L L F M$} & $E x$. & 4.85 & 1.57 & 2.20 & 8.20 & 4.61 & 1.40 & 2.20 & 7.10 & -0.24 \\
\hline & Co. & 4.45 & 1.01 & 2.80 & 6.60 & 4.28 & 0.82 & 2.80 & 6.10 & -0.17 \\
\hline \multirow{2}{*}{$L L \% F M$} & $E x$. & 36.82 & 6.98 & 22.10 & 46.10 & 35.46 & 6.66 & 23.00 & 44.10 & -1.36 \\
\hline & Co. & 35.58 & 4.59 & 26.90 & 42.10 & 35.04 & 3.66 & 26.60 & 41.10 & -0.54 \\
\hline \multirow{2}{*}{ LL FFM } & $E x$. & 8.00 & 0.63 & 7.20 & 9.60 & 8.12 & 0.75 & 7.00 & 9.40 & 0.12 \\
\hline & Co. & 7.94 & 0.91 & 6.40 & 9.20 & 7.85 & 0.73 & 6.50 & 9.20 & -0.09 \\
\hline \multirow{2}{*}{$L L \% F F M$} & $E x$. & 63.16 & 7.00 & 53.90 & 77.90 & 64.54 & 6.66 & 55.90 & 77.00 & 1.38 \\
\hline & Co. & 64.94 & 4.93 & 57.90 & 73.10 & 65.02 & 3.75 & 58.90 & 73.40 & 0.08 \\
\hline
\end{tabular}

Legend: $R L$ - right leg, $L L$ - left leg, \%MM, \%FM, \%FFM - muscle mass, fat mass, fat free mass [\%], $M M, F M, F F M$ - muscle mass, fat mass, fat-free mass [kg], Ex. - experimental group, Co. - control group, Before - values before the active intervention of the experimental group, After - values after the active intervention of the experimental group, $M$ - arithmetic mean, $S D$ - standard deviation, Min. - minimum value, Max. - maximum value, Change - difference between the mean value after and before exercise intervention

It cannot be ruled out that, in those women who had final average rates $\mathrm{VO}_{2}$ peak and $\mathrm{VO}_{2}$ peak $\times \mathrm{kg}^{-1}$ higher than women from the experimental group, unrecorded positive changes in their lifestyle occurred which may reverse the age related digressive trend of aerobic capacity (Fletcher et al., 2001; Hawkins \& Wiswell, 2003). Among these possible unregistered changes can belong, for example, a seasonal rise in habitual activity, which could raise the final values of both monitored indicators.

$\mathrm{VO}_{2}$ peak $\times \mathrm{kg}^{-1}$ enhancement in the women from the experimental group is lower than other similar studies mention (Robles Gil et al., 2012; Stejskal et al., 2007). In these studies the $\mathrm{VO}_{2}$ peak $\times \mathrm{kg}^{-1}$ increasing was higher than $3.5 \mathrm{ml} \times \mathrm{kg}^{-1} \times \mathrm{min}^{-1}$, but participants completed aerobic dance lessons without strength training and with higher training intensity.

The recommended intensity of the workout corresponded to approximately $60 \% \mathrm{VO}_{2} \max \times \mathrm{kg}^{-1}$ (Stejskal \& Hejnová, 1993) or $60 \%$ HRR. The actual values of loading of circulation were, on average, approximately $5 \%$ lower and the involvement of individual women was markedly different. From the results of heart rate monitors, it is evident that the average exercise time at the training intensity above $40 \%$ HRR was almost 38 minutes and at the training intensity above $50 \%$ HRR was almost 30 minutes.

This active intervention should lead to an improvement in fitness, due to its frequency, duration, and intensity being distinctively over the recommended limit of the American Heart Association (AHA) - three times a week, 20 minutes, minimum intensity $40 \% \mathrm{VO}_{2} \max$ (Fletcher et al, 2001). ACSM also mention, that for unfit individuals, training intensity $40-50 \%$ HRR is sufficient to improve cardiorespiratory fitness (Pollock et al., 1998). Swain and Franklin (2002) demonstrate in their study that persons with baseline aerobic capacity below $40 \mathrm{ml} \times \mathrm{kg}^{-1} \times \mathrm{min}^{-1}$ obtain improvement in $\mathrm{VO}_{2} \max$ with training intensity as low as $30 \%$ of HRR. Higher 
TABLE 5

Results of the Fisher's LSD test and ANOVA at repeated measurements

\begin{tabular}{|c|c|c|c|c|c|c|c|}
\hline \multirow{4}{*}{ Indicator } & \multicolumn{4}{|c|}{ Post hoc - Fisher's LSD test } & \multirow{3}{*}{\multicolumn{3}{|c|}{ ANOVA }} \\
\hline & \multicolumn{2}{|c|}{ Before vs. After } & \multicolumn{2}{|c|}{ Ex. vs. Co. } & & & \\
\hline & Ex. & Co. & Before - Before & After - After & & & \\
\hline & $p$ & $p$ & $p$ & $p$ & $F$ & $p$ & $\eta^{2}$ \\
\hline Weight & 0.28 & 0.07 & 0.50 & 0.67 & 0.36 & 0.55 & 0.01 \\
\hline BMI & 0.15 & 0.02 & 0.29 & 0.19 & 0.50 & 0.48 & 0.01 \\
\hline$T M M$ & 0.76 & 0.60 & 0.96 & 0.73 & 0.36 & 0.55 & 0.01 \\
\hline$\% T M M$ & 0.12 & 0.60 & 0.54 & 0.74 & 0.52 & 0.47 & 0.01 \\
\hline TFM & 0.10 & 0.28 & 0.36 & 0.43 & 0.12 & 0.73 & $<0.00$ \\
\hline$\% T F M$ & 0.17 & 0.62 & 0.56 & 0.73 & 0.37 & 0.55 & 0.01 \\
\hline TFFM & 0.01 & 0.10 & 0.93 & 0.50 & 1.84 & 0.18 & 0.05 \\
\hline$\%$ TFFM & 0.18 & 0.46 & 0.62 & 0.74 & 0.16 & 0.69 & $<0.00$ \\
\hline Impedance & 0.50 & 0.35 & 0.62 & 0.25 & 1.32 & 0.26 & 0.03 \\
\hline$T B W$ & 0.88 & 0.07 & 0.90 & 0.45 & 2.11 & 0.15 & 0.05 \\
\hline$\% T B W$ & 0.21 & 0.47 & 0.65 & 0.76 & 0.13 & 0.72 & $<0.00$ \\
\hline$R L M M$ & 0.08 & 0.22 & 0.81 & 0.47 & 4.72 & 0.04 & 0.11 \\
\hline$R L \% M M$ & 0.01 & 0.30 & 0.35 & 0.60 & 1.05 & 0.31 & 0.03 \\
\hline$R L F M$ & 0.03 & 0.11 & 0.28 & 0.34 & 0.17 & 0.69 & $<0.00$ \\
\hline$R L \% F M$ & 0.01 & 0.37 & 0.34 & 0.66 & 1.75 & 0.19 & 0.04 \\
\hline$R L F F M$ & 0.06 & 0.20 & 0.82 & 0.43 & 5.23 & 0.03 & 0.12 \\
\hline$R L \% F F M$ & 0.24 & 0.41 & 0.13 & 0.70 & 2.04 & 0.16 & 0.05 \\
\hline$L L M M$ & 0.15 & 0.15 & 0.80 & 0.24 & 3.12 & 0.09 & 0.08 \\
\hline$L L \% M M$ & 0.01 & 0.35 & 0.49 & 0.86 & 1.37 & 0.25 & 0.03 \\
\hline$L L F M$ & 0.02 & 0.13 & 0.31 & 0.41 & 0.25 & 0.62 & 0.01 \\
\hline$L L \% F M$ & 0.02 & 0,38 & 0.50 & 0.82 & 0.97 & 0.33 & 0.02 \\
\hline LL FFM & 0.20 & 0.34 & 0.80 & 0.27 & 2.55 & 0.12 & 0.06 \\
\hline$L L \% F F M$ & 0.03 & 0.90 & 0.34 & 0.79 & 2.20 & 0.15 & 0.05 \\
\hline $\mathrm{VO}_{2}$ peak & 0.01 & 0.06 & 0.49 & 0.72 & 0.29 & 0.60 & 0.01 \\
\hline $\mathrm{VO}_{2}$ peak $\times \mathrm{kg}^{-1}$ & $<0.00$ & 0.01 & 0.30 & 0.40 & 0.07 & 0.80 & $<0.00$ \\
\hline$W_{\max }$ & 0.08 & 0.45 & 0.99 & 0.34 & 3.29 & 0.08 & 0.08 \\
\hline$W_{\max } \times k^{-1}$ & 0.06 & 0.87 & 0.79 & 0.64 & 1.44 & 0.24 & 0.04 \\
\hline$H R_{\max }$ & 0.80 & 0.04 & 0.84 & 0.31 & 2.97 & 0.09 & 0.07 \\
\hline Test duration & 0.01 & 0.14 & 0.77 & 0.41 & 8.51 & 0.01 & 0.18 \\
\hline
\end{tabular}

Legend: Weight - women's weight [kg], BMI - body mass index [ $\left.\mathrm{kg} \times \mathrm{m}^{-2}\right], \% T M M, \% T F M, \% T F F M$ - total muscle mass, total fat mass and total fat-free mass [\%], TMM, TFM, TFFM - total muscle mass, total fat mass and total fat-free mass [kg], Impedance - total body impedance $[\Omega], T B W$ - total body water [kg], \% TBW - total body water [\%], $R L$ - right leg, $L L$ - left leg, \%MM, \%FM, \%FFM - muscle mass, fat mass, fat-free mass [\%], MM, FM, FFM - muscle mass, fat mass, fat-free mass [kg], VO,peak - peak oxygen consumption [L $\left.\times \min ^{-1}\right]$, $V O_{2}$ peak $\times \mathrm{kg}^{-1}$ - peak oxygen consumption $\left[\mathrm{ml} \times \mathrm{min}^{-1} \times \mathrm{kg}^{-1}\right], W_{\max }$ - maximum performance [W], $W \times \mathrm{kg}^{-1}$ - maximum performance $\left[\mathrm{W} \times \mathrm{kg}^{-1}\right], H R_{\max }-$ maximum heart rate [beats $\times \mathrm{min}^{-1}$ ], Test duration - duration of the exercise test [min.], Ex. - experimental group, Co. - control group, Before - values before the active intervention of the experimental group, After - values after the active intervention of the experimental group, ANOVA - ANOVA at repeated measurements, $F$ - value of the test criterion, $P$ - level of statistical significance, $\eta^{2}$ - logical significance coefficient

intensity of training is generally more effective at improving $\mathrm{VO}_{2}$ max, however, vigorous exercise can evocate injury, cardiovascular complications (Swain \& Franklin, 2002) or lower adherence to exercise program (Willis \& Campbell, 1992) by persons with lower fitness.

Stejskal et al. (2007) in their study also noted high variability of values characterizing training intensity and the time that their participants spent within the recommended zone. Even if it was dance aerobics or step aerobics lessons without strength training, average training intensity was approximately $54.8 \%$ HRR and the time spent within the recommended zone was on average 18.5 minutes.

The intensity of aerobics can be influenced by many factors. One of them is the structure of the lesson. According to Bell and Bassey (1994), exercise intensity can 
be objectively influenced by the addition of arm work during workout, by the cadence of the music or by the number of high impact elements in the choreography. Aerobic dance composed entirely of high impact elements is more intensive, which is better for increasing physical fitness (Grant, Davidson, Aitchison, \& Wilson, 1998). However, high impact styles evocates a higher load on weight-bearing joints (Ricard \& Veatch, 1990). According to Heinonen et al. (1996), exercise consisting of only high impact elements may help decrease the risk of onset osteoporosis in later life. In light of the higher risk of injuries to legs, hips, and the lower back it is preferable to use low impact elements in aerobic dance (Bell \& Bassey, 1994; Grand et al., 1998). Regarding to the fact that women, who took part in this study, were middle aged, slightly overweight, untrained and sedentary, aerobic dance composed mainly of low impact elements (even if the intensity is lower) was suitable for them and according to some authors should also improve aerobic capacity (Bell \& Bassey, 1994; Grand et al., 1998).

A different level of motivation and ability or willingness to follow an instructor's advice and to perform particular elements technically right and in a proper amount can also influence the intensity of aerobic dance. Laukkanen et al. (2001) discuss in their study, that training intensity in aerobics lessons can be influenced by the different previous participants' experiences with aerobics. Women with previous experiences with some types of aerobics are more successful in intensity management during the aerobics classes. From the short entrance interviews ensued, that more than half of women, who participated in this study, had a minimal previous experiences with aerobics. This fact certainly had an influence on time spent in the recommended zone, training intensity and the structure of the lessons.

If the physical activity is to have a positive effect on body composition or aerobic capacity, then its training intensity should be adapted to the physical fitness of each subject. For less fit individuals, moderately intense exercise is sufficient for improving cardiorespiratory fitness; subjects with markedly higher aerobic power require high intensity exercise for further improvement of their fitness (Swain \& Franklin, 2002). From this point of view, group exercise, which is conformed to less fit subjects, can be less efficient for more fit subjects, as Stejskal et al. (2007) confirm in their study as well.

The presented results of the functional examination can be interpreted to have been less efficient when considering the impact the used active intervention had on aerobic performance. The reason can be seen in the above-mentioned influences, primarily in the low and particularly in the diversely different adherence to the program, and the low (and therefore inefficient) intensity of training. Provided that a standard sample of middle aged women with a common approach to changes in life style has been chosen, then a positive influence of the realized physical intervention on their health cannot be expected. Other authors (Wilmore et al., 1999) have also corroborated the conclusion that relatively short and less intensive physical activity usually has no relevant influence on the body's composition and some circulatory or metabolic parameters.

Limitations of this study are that the women were not divided randomly into experimental and control group. Randomization would guarantee higher validity of the presented study, but for above-mentioned reasons a randomization could not be done. Presumption, that dividing women into the experimental and the control group on the basis on their interest in physical activity will cause higher adherence to the intervention program, was not confirmed.

\section{CONCLUSION}

The goal of the study was to assess the influence of a six-month active intervention (specific aerobics lessons) on the body composition and aerobic capacity of middle aged women with a sedentary occupation and no regular exercise.

The achieved results from monitoring the effects of aerobics exercises on anthropometric data were negatively influenced by the relatively poor attendance at the aerobics lessons, large differences in the approach to exercise, diminishing motivation towards exercise, and the relatively low training intensity. Habitual activity (which was not observed) and its changes during the intervention could have also played a role.

Although the active intervention did not generally prove a significant improvement in the monitored indicators, the differences between the experimental group and the control group are evident from the results.

The significant enhancement in aerobic capacity was attained in both groups, women from the experimental group, in contrast to the control group, improved significantly the duration of the exercise examination and increased their maximum performance as well.

In addition, a hint of a positive effect of chosen intervention programme can be seen in the changes of body composition. Whereas in the experimental group, on average, body fat declined and muscle mass rose, in the control group the amount of fat free mass declined.

\section{REFERENCES}

Asikainen, T. M., Kukkonen-Harjula, K., \& Miilunpalo, S. (2004). Exercise for health for early postmenopausal women: A systematic review of randomised controlled trials. Sports Medicine, 34(11), 753-778.

Asikainen, T. M., Miilunpalo, S., Oja, P., Rinne, M., Pasanen, M., Uusi-Rasi, K., \& Vuori, I. (2002). Ran- 
domised, controlled walking trials in postmenopausal women: The minimum dose to improve aerobic fitness? British Journal of Sports Medicine, 36(3), 189-194.

Bell, J. M., \& Bassey, E. J. (1994). A comparison of the relation between oxygen uptake and heart rate during different styles of aerobic dance and a traditional step test in women. European Journal of Applied Physiology, 68(1), 20-24.

Boháčková, L., \& Kolouch, V. (2001). Optimalizace pohybového režimu perimenopauzálních žen. In Sborník príspěvků národní konference „Sport v české republice na začátku nového tisíciletí, 2“(pp.97-100). Praha: Karlova univerzita, Fakulta tělesné výchovy a sportu.

Çakmakçi, E., Arslan, F., Taşkin, H., \& Çakmakçi, O. (2011). The effects of aerobic dance exercise on body composition changes associated with weight change in sedentary women. Selçuk University Journal of Physical Education and Sport Science, 13(3), 298-304.

Fletcher, G. F. et al. (2001). Exercise standards for testing and training: A statement for healthcare professionals from the American heart association. Circulation, 104(14), 1694-1740.

Grant, S., Davidson, W., Aitchison, T., \& Wilson, J. (1998). A comparison of physiological responses and rating of perceived exertion between high-impact and low-impact aerobic dance sessions. European Journal of Applied Physiology and Occupational Physiology, 78(4), 324-332.

Hawkins, S. A., \& Wiswell, R. A. (2003). Rate and mechanism of maximal oxygen consumption decline with aging. Sports Medicine, 33(12), 877-888.

Heinonen, A., Kannus, P., Sievänen, H., Oja, P., Pasanen, M., Rinne, M., Uusi-Rasi, K., \& Vuori, I. (1996). Randomised controlled trial of effect of highimpact exercise on selected risk factors for osteoporotic fractures. The Lancet, 348(9038), 1343-1347.

Heyward, V. H., \& Wagner, D. R. (2004). Applied body composition assessment (2nd ed.). Champaign, IL: Human Kinetics.

Hughes, V. A., Frontera, W. R., Roubenoff, R., Evans, W. J., \& Fiatarone Singh, M. A. (2002). Longitudinal changes in body composition in older men and women: Role of body weight change and physical activity. American Journal of Clinical Nutrition, 76, 473-481.

Chobanian, A. V. et al. (2003). Seventh report of the joint national committee on prevention, detection, evaluation, and treatment of high blood pressure. Hypertension, 42, 1206-1252.

Jirák, Z., Šimíček, J., Tomášková, H., Bužga, M., Zavadilová, V., Čermáková, Z., \& Tesař, Z. (2004). Vývoj fyzické zdatnosti a zdravotní stav mužské a ženské populace severomoravského regionu ve věku 45 až
60 let za posledních 25 let. České pracovní lékařství, 5(3), 107-116.

Jones. A. M., \& Carter, H. (2000). The effect of endurance training on parameters of aerobic fitness. Sports Medicine, 29(6), 373-386.

Kováčová, L., Stejskal, P., Neuls, F., \& Elfmark, M. (2011). Adherence to the aerobics exercise program in women aged 40 to 65 . Acta Universitatis Palackianae Olomucensis. Gymnica, 41(2), 55-63.

Kyle, U. G. et al. (2004). Bioelectrical impedance analysis - part II: Utilization in clinical practice. Clinical Nutrition, 23, 1430-1453.

Laukkanen, R. M., Kalaja, M. K., Kalaja, S. P., Holmala, E. B., Paavolainen, L. M., Tummavuori, M., Virtanen, P., \& Rusko, H. K. (2001). Heart rate during aerobics classes in women with different previous experience of aerobics. European Journal of Applied Physiology, 84(1-2), 64-68.

Manolagas, S. C. (2010). From estrogen-centric to aging and oxidative stress: A revised perspective of the pathogenesis of osteoporosis. Endocrine Reviews, 31(3), 266-300.

Morse, D. T. (1999). Minisize2: A computer program for determining effect size and minimum sample for statistical significance for univariate, multivariate, and nonparametric tests. Educational and Psychological Measurement, 59(3), 518-531.

National Heart, Lung, and Blood Institute. (1998). Clinical guidelines on the identification, evaluation, and treatment of overweight and obesity in adults. The evidence report. [NIH publication no. 98-4083]. Bethesda, MD: Department of Health and Human Services, National Institutes of Health.

Placheta, Z. Siegelová, J., Svačinová, H., Štejfa, M., Jančík, J., Homolka, P., \& Dobšák, P. (2001). Zátěžové vyšetrení a pohybová léčba ve vnitřním lékařství. Brno: Masarykova univerzita.

Pollock, M. L., Gaesser, G. A., Butcher, J. D., Després, J. P., Dishman, R. K., Franklin, B. A., \& Garber, C. E. (1998). ACSM position stand: The recommended quantity and quality of exercise for developing and maintaining cardiorespiratory and muscular fitness, and flexibility in healthy adults. Medicine \& Science in Sports \& Exercise, 30(6), 975-991.

Ricard, M. D., \& Veatch, S. (1990). Comparison of impact forces in high and low impact aerobic dance movements. International Journal of Sport Biomechanics, 6(1), 67-77.

Riegerová, J., Přidalová, M., \& Ulbrichová, M. (2006). Aplikace fyzické antropologie v tělesné výchově a sportu: príručka funkční antropologie (3rd ed.). Olomouc: Hanex.

Robles Gil, M. C., Timón, R., Toribio, A. F., Muñoz, D., Maynar, J. I., Caballero, M. J., \& Maynar, M. (2012). Effects of aerobic exercise on urinary estrogens and progestagens in pre and postmenopausal women. 
European Journal of Applied Physiology, 112(1), 357-364.

Salinger, J., Opavský, J., Stejskal, P., Vychodil, R., Olšák, S., \& Janura, M. (1998). The evaluation of heart rate variability in physical exercise by using the telemetric VariaPulse TF3 system. Acta Universitatis Palackianae Olomucensis. Gymnica, 28, 13-23.

Silva, R. B., Costa-Paiva, L., Pinto-Neto, A. M., Braga, A., \& Morais, S. S. (2005). Association between habitual physical activity and parameters of physical fitness in postmenopausal women. Climacteric, 8(4), $360-371$.

Stejskal, P. (2000). Obesity, energy balance and its regulation. Acta Universitatis Palackianae Olomucensis. Gymnica, 30(2), 7-17.

Stejskal, P., \& Hejnová, J. (1992). Preskripce intenzity zatížení v programu kontinuální tělesné aktivity. Medicina Sportiva Bohemica \& Slovaca, 1(4), 11-16.

Stejskal, P., \& Hejnová, J. (1993). Praktické problémy preskripce intenzity zatížení v rámci programu tělesné aktivity. Medicina Sportiva Bohemica \& Slovaca, 2(2), 76-81.

Stejskal, P., Jakubec, A., Kováčová, L., Elfmark, M., Řehová, I., Petr, M., \& Cipryan, L. (2007). Vliv rozdílné adherence $\mathrm{k}$ půlročnímu programu aerobiku na aerobní zdatnost. Medicina Sportiva Bohemica et Slovaca, 16(1), 14-25.

Swain, D. P., \& Franklin, B. A. (2002). VO reserve and the minimal intensity for improving cardiorespiratory fitness. Medicine \& Science in Sports \& Exercise, 34(1), 152-157.

Šimonek, J. (2000). Pohybová aktivita v živote súčasného človeka. In Pohybová aktivita žien (pp. 23-65). Bratislava: Slovenský olympijský výbor.

Šeděnková, B. (2007). Současné metody výuky choreografie v lekcích aerobiku. In Soubor referátů z mezinárodních seminářu Pedagogické kinantropologie konaných 29.-31. března 2006, 28.-30. března 2007 (pp. 198-202). Ostrava: Ostravská univerzita v Ostravě.

Tanita. Body Composition Analyzer - BC 418 MA Instruction Manual and Technical Notes. (2002). Tokyo, Japan: Tanita Corporation.

Wagner, D. R., \& Heyward, V. H. (1999). Techniques of body composition assessment: A review of laboratory and field methods. Research Quarterly for Exercise and Sport, 70(2), 135-149.

Warburton, D. E., Nicol, C. W., \& Bredin, S. S. (2006). Health benefits of physical activity: The evidence. $\mathrm{Ca}$ nadian Medical Association Journal, 174(6), 801-809.

Willis, J. D., \& Campbell, L. F. (1992). Exercise psychology. Champaign, IL: Human Kinetics.

Wilmore, J. H., Després, J. P., Stanforth, P. R., Mandel, S., Rice, T., Gagyon, J., Leon, A. S., Rao, D. C., Skinner, J. S., \& Bouchard, C. (1999). Alterations in body weight and composition consequent to
20 week of endurance training: the heritage family study. American Journal of Clinical Nutrition, 70(3), 346-352.

\section{VLIV PŮLROČNÍHO PROGRAMU AEROBIKU NA AEROBNÍ KAPACITU A TĚLESNÉ SLOŽENÍ ŽEN STŘEDNÍHO VĚKU}

(Souhrn anglického textu)

VÝCHODISKA: Pravidelná pohybová aktivita vytrvalostního charakteru působí pozitivně na zvýšení tělesné zdatnosti, což významně ovlivňuje zdraví a následně kvalitu a délku života.

CÍLE: Cílem studie bylo posoudit vliv půlroční pohybové intervence vytrvalostního charakteru na tělesné složení a aerobní kapacitu u žen středního věku.

METODIKA: Testovaný soubor tvořilo 40 žen ve věku 40-55 let se sedavým zaměstnáním a bez pravidelné pohybové aktivity. Experimentální skupina $(n=21)$ absolvovala po dobu šesti měsíců třikrát týdně pravidelné lekce tanečního aerobiku kombinovaného s posilováním, v jejichž průběhu jim byla pomocí monitorů měřena srdeční frekvence. Kontrolní skupina ( $n=19)$ za stejné období nezměnila svůj životní styl. Před a po ukončení pohybové intervence se ženy podrobily zátěžovému vyšetření a antropometrickému měření (tetrapolární bioelektrická impedance).

VÝSLEDKY: Po ukončení intervence byly ve skupině cvičících žen zaznamenány pozitivní změny téměř u všech sledovaných parametrů, přičemž zvýšení tukuprosté hmoty dolních končetin, vrcholové spotřeby kyslíku a délky trvání zátěžového testu bylo statisticky významné. Přestože se některé sledované parametry u kontrolní skupiny změnily téměř identicky, množství tukuprosté hmoty u těchto žen kleslo a délka trvání zátěžového testu se zkrátila. Analýza rozptylu při opakovaných měřeních potvrdila, že intervenční program měl statisticky významný pozitivní vliv na tukuprostou a svalovou hmotu pravé dolní končetiny a délku trvání zátěžového testu.

ZÁVĚRY: Pohybová intervence měla statisticky významný vliv pouze na délku trvání zátěžového testu a množství tukuprosté a svalové hmoty na pravé dolní končetině. Výsledky byly ovlivněny nízkou adherencí žen ke cvičení a většinou nízkou intenzitou zatížení. I přes některé rozporuplné výsledky lze říci, že pohybová intervence formou tanečního aerobiku kombinovaného s posilováním je vhodnou pohybovou aktivitou pro zvýšení tělesné zdatnosti u žen středního věku se sedavým zaměstnáním.

Kličová slova: bioelektrická impedance, tuková hmota, kardiorespirační zdatnost, taneční aerobik, ženy se sedavým zaměstnáním. 


\section{Mgr. Barbora Šeděnková}

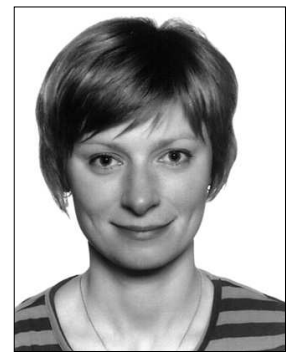

Palacký University, Olomouc

Faculty of Physical Culture

tř. Míru 115

77111 Olomouc

Czech Republic

\section{Education and previous work experience}

1999-2004 - Master study at Pedagogical Faculty, University of Ostrava.

2003-2005 - physical education teacher at Grammar school, Bílovec.

2005-2009 - lecturer at Department of Physical Education, Pedagogical Faculty, University of Ostrava.

Since 2006 - Ph.D. student at the Faculty of Physical Culture, Palacký University, Olomouc

2002 - 1st class aerobics instructor.

\section{First-line publication:}

Šeděnková, B. (2007). Současné metody výuky choreografie v lekcích aerobiku. In Soubor referátů z mezinárodních seminárů Pedagogické kinantropologie konaných 29.-31. března 2006, 28.-30. března 2007 (pp. 198-202). Ostrava: Ostravská univerzita v Ostravě.

Šeděnková, B., \& Stejskal, P. (2010). Změny variability srdeční frekvence po šestiměsíčním programu aerobiku u žen středního věku. Medicina Sportiva Bohemica et Slovaca, 19(4), 248-253.

Šimíček, J., Šeděnková, B., Raníková, B., \& Bušinová, T. (2008). Posouzení tělesné zdatnosti vybraných žen na Ostravsku. In Soubor referátů z mezinárodního semináre Pedagogické kinantropologie konaného 9.-11. dubna 2008 (pp. 129-133). Ostrava: Ostravská univerzita v Ostravě. 